\title{
The Effect of Different Chemical Agents on the Prevention of Enzymatic Browning in Banana
}

\author{
Gulcin Yildiz \\ Food Engineering Department, Faculty of Engineering, Igdir University, Igdir 76000, Turkey
}

\begin{abstract}
This study was conducted to test the concept of fresh cut banana slices with the effects of chemical treatments on the surface appearance and selected quality indexes of banana samples right after cutting and during 2-week of storage at refrigeration conditions $\left(0-4{ }^{\circ} \mathrm{C}\right)$. Banana slices were treated with an ascorbic acid, sodium chloride, citric acid, calcium chloride, and sodium carbonate, water (room temperature), and hot water $\left(65^{\circ} \mathrm{C}\right)$. Quality attributes, e.g. color, PPO (polyphenol oxidase) activities, surface appearance of the cut bananas were compared. Banana slices immersed in sodium chloride, calcium chloride, citric acid and sodium ascorbate showed visual traces of browning during storage at $4{ }^{\circ} \mathrm{C}$. After 14 days of storage, only ascorbic acid treated banana samples showed moderate browning, while all other treatments were severely affected. Browning was more severe for the samples immersed in water for all storage times. The browning measurement ( $a$ value) became increasingly positive from first to fourteenth day storage. It was observed that the inactivation of PPO enzyme was achieved for the ascorbic acid treated sample most. Rather than ascorbic acid treatment, cut banana samples showed less PPO enzyme activity for sodium chloride, citric acid, calcium chloride, sodium carbonate, hot water, and water (room temperature) treatments, subsequently. There were no significant changes observed on the different chemical treatments (sodium chloride, citric acid, calcium chloride, and sodium carbonate) except ascorbic acid. In overall, ascorbic acid was found to be the most efficient treatment on the inactivation of PPO enzyme activity among all the treatments. Beside the inactivation of the enzyme, ascorbic acid showed a better success to prevent color degradation of bananas. This study showed that ascorbic acid treatment is an effective chemical agent on the inactivation of browning enzymes.
\end{abstract}

Key words: Enzymatic browning, color, ascorbic acid, PPO enzyme, banana.

\section{Introduction}

In the fresh cut food industry, enzymatic browning has a very important role. This type of browning discoloration not only reduces the shelf life of several processed foods, but also negatively impacts the quality of frozen fruits and vegetables [1,2]. Because of enzymatic browning almost half of tropical fruits are discarded because of the quality defects [3]. The browning is mainly catalyzed by the enzyme called as PPO (polyphenol oxidase) which is also known as phenoloxidase, phenolase, monophenol oxidase, diphenol oxidase and tyrosinase [4]. When plant tissues are damaged by physical effects such as cutting, bruising or blending, PPO is activated by releasing into the cytosol. In the presence of atmospheric

Corresponding author: Gulcin Yildiz, Ph.D., research field: food processing and engineering. oxygen and PPO, monophenol is hydroxylated to $o$-diphenol and diphenol can be oxidized to o-quinones, which then undergoes polymerization to produce dark brown polymers (Fig. 1) [5].

The browning reaction could be slowed down or prevented by inactivating the enzyme with some processes such as heat, reducing the $\mathrm{pH}$ on the surface of the fruit (e.g. adding lemon juice or another acids), reducing the amount of available oxygen (e.g. putting cut fruit under water or vacuum packing it), or by adding certain preservative chemicals (such as sulfur dioxide) [6-8]. This work was undertaken to investigate the effect of different chemical treatments (ascorbic acid, sodium chloride, citric acid, calcium chloride, and sodium carbonate) in addition to water (room temperature) and hot water $\left(65^{\circ} \mathrm{C}\right)$ treatments on the prevention of enzymatic browning in banana during two weeks of storage at refrigeration conditions 

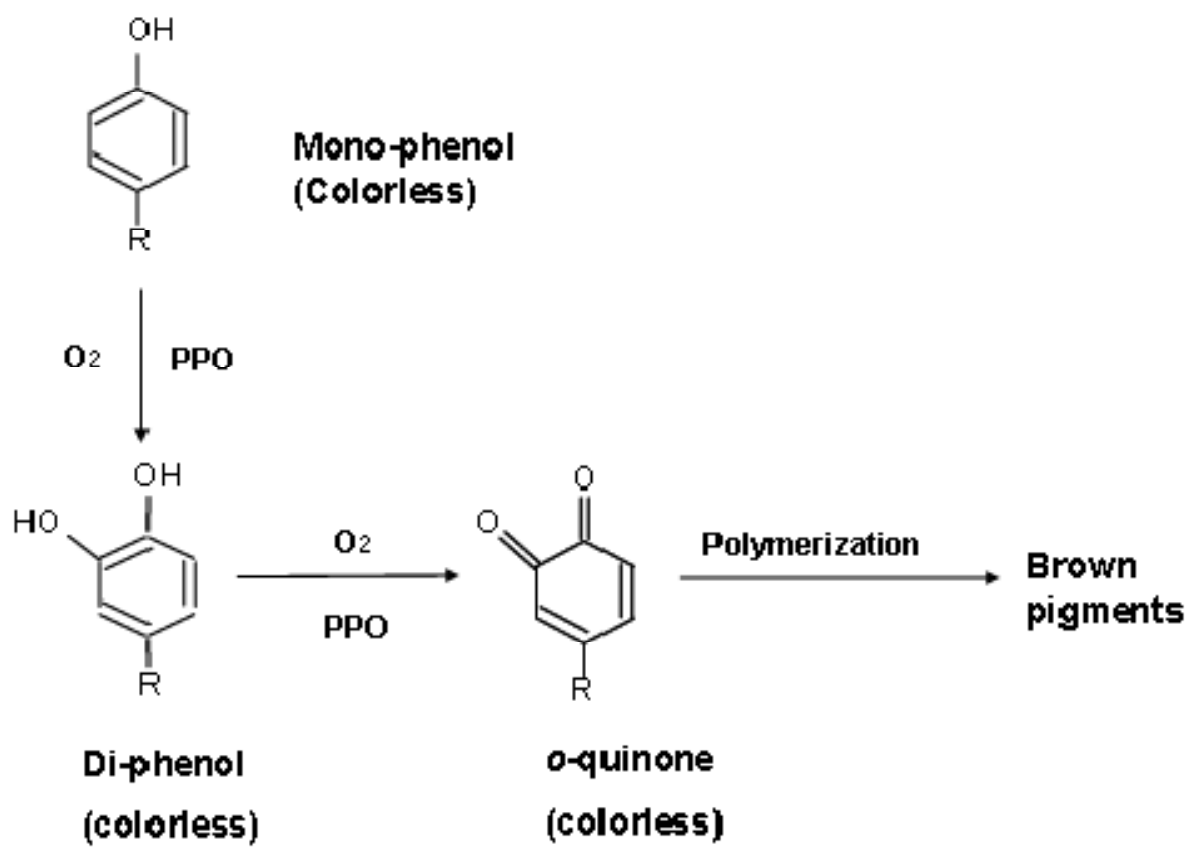

Fig. 1 Schematic representation of oxidation reaction by PPO. Source: Ref. [5].

$\left(0-4{ }^{\circ} \mathrm{C}\right)$. PPO enzyme activities of banana samples treated with different methods were compared. Color changes of the samples were measured. And finally, surface appearance of the cut bananas was compared.

\section{Methodology}

Banana was chosen for this study due to its high susceptibility to browning. Bananas (Lefruit D'OR) grown in Ecuador were purchased from a local market. All chemicals including ascorbic acid, sodium chloride, citric acid, calcium chloride, and sodium carbonate were obtained from the Sigma-Aldrich company (St. Louis, MO, USA). Bananas with uniform size and color were peeled and cut into five equal slices using a sharp stainless steel knife. One of the slices was dipped in solution of $1 \%$ ascorbic acid, sodium chloride, citric acid, calcium chloride, and sodium carbonate separately for $3 \mathrm{~min}$, drained with a paper towel, placed in polyethylene bags, and kept under the refrigerated conditions $\left(0-4{ }^{\circ} \mathrm{C}\right)$ during 2 weeks for the shelf life study. Experiments were done in triplicate. Beside the chemical treatments, sliced banana samples were immersed directly in water at room temperature, and $65^{\circ} \mathrm{C}$ water separately for 3 min.

Colors of the banana surfaces were measured with a Minolta Chroma Meter by directly holding the device vertically to the surface of the samples. The color meter was calibrated with a white standard plate. The numerical values of the color readings were expressed by the lightness (L), redness (a, tred-green) and yellowness (b, tyellow-blue). For each sample color values $(\mathrm{L}, \mathrm{a}$, and $\mathrm{b})$ were read 5 times at different locations on the sample surface (one reading was from the center, one from the left-top side, one from the right-top side, one from the left-bottom, and one from right-bottom of the sample) at room temperature. Then these values were averaged, and only one number was obtained for $\mathrm{L}$, $\mathrm{a}$, and $\mathrm{b}$ values. For color analysis, 3 replications were used. Color analysis was done for the 0 , seventh and fourteenth days [9].

Photos of control and treated banana samples were 
taken by a camera (Sony Cyber-Shot DSC-W570 16.1 MP Digital Still Camera) (Fig. 2).

The method proposed by Montgomery and Sgarbieri [10] was followed to determine PPO activity in the banana samples using a spectrophotometer. Thirty grams of tissue were homogenized using a blender in $0.2 \mathrm{~g}$ PVPP (poly vinyl poly pirrolidone) and $70 \mathrm{~mL}$ of $0.5 \mathrm{M}$ phosphate buffer (pH 6.8) for 50 seconds. The homogenate was filtered through filter paper under vacuum to remove cellular debris. The clear supernatant after centrifugation at 1,200 $\mathrm{g}$ for 15 min at $15-20{ }^{\circ} \mathrm{C}$ was collected as enzyme extracts. Two milliliters of phosphate buffer $(0.05 \mathrm{M})$ stored in a refrigerator at $4{ }^{\circ} \mathrm{C}$ and $0.5 \mathrm{~mL}$ enzyme extract were added to a glass tube. Before the reading, $0.5 \mathrm{~mL}$ catechol $(0.02 \mathrm{M})$ prepared fresh daily was added to the mixture. The mixture was poured into cuvettes and inserted in a plate reader. The increase in absorbance was read over $3 \mathrm{~min}$ in every $15 \mathrm{~s}$ at $420 \mathrm{~nm}$. The PPO activity analysis was done at the 0 , seventh and fourteenth days. The absorbance $(420 \mathrm{~nm})$ of the assay solution was plotted against the reaction time (180 s) to demonstrate the enzyme kinetics. Slope of the absorbance vs. time curve was calculated, and the result was reported as a "U/g FW" (see Fig. 3 as an example for absorbance vs. time curve of banana samples treated with ascorbic acid). Since one unit of enzyme activity is defined as the amount of enzyme causing a change in absorbance of 0.001 per minute, the data were divided by 0.001 and PPO activity was reported as "U/mL" according to formula proposed by Cemeroglu [11].

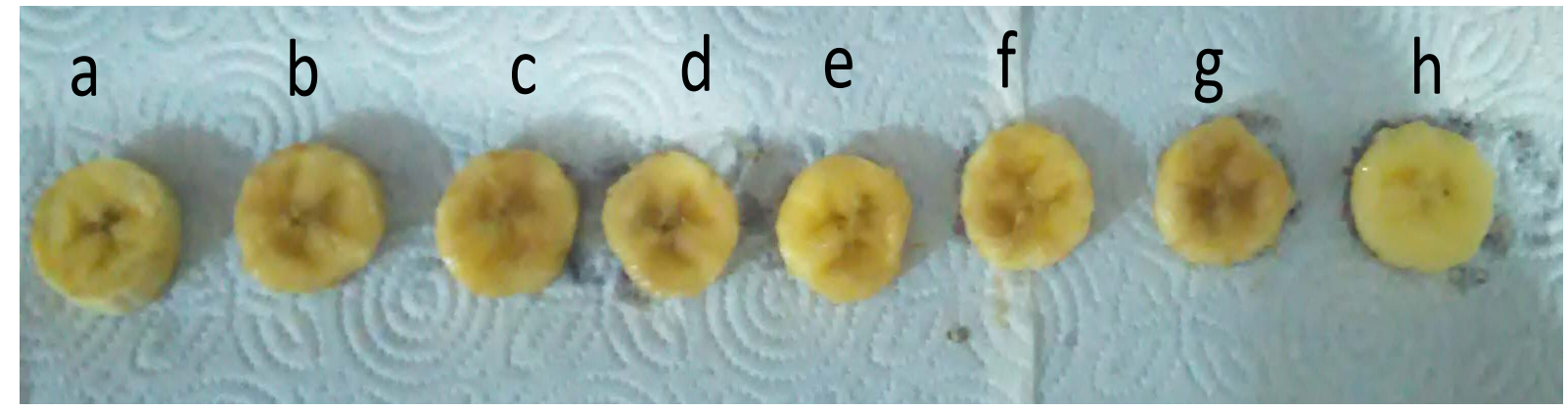

Fig. 2 Appearance of banana slices with different treatments.

Source: a: no treatment; b: water (room temperature); c: hot water $\left(65^{\circ} \mathrm{C}\right)$; d: sodium chloride; e: citric acid; f: calcium chloride; g: sodium carbonate; h: ascorbic acid.

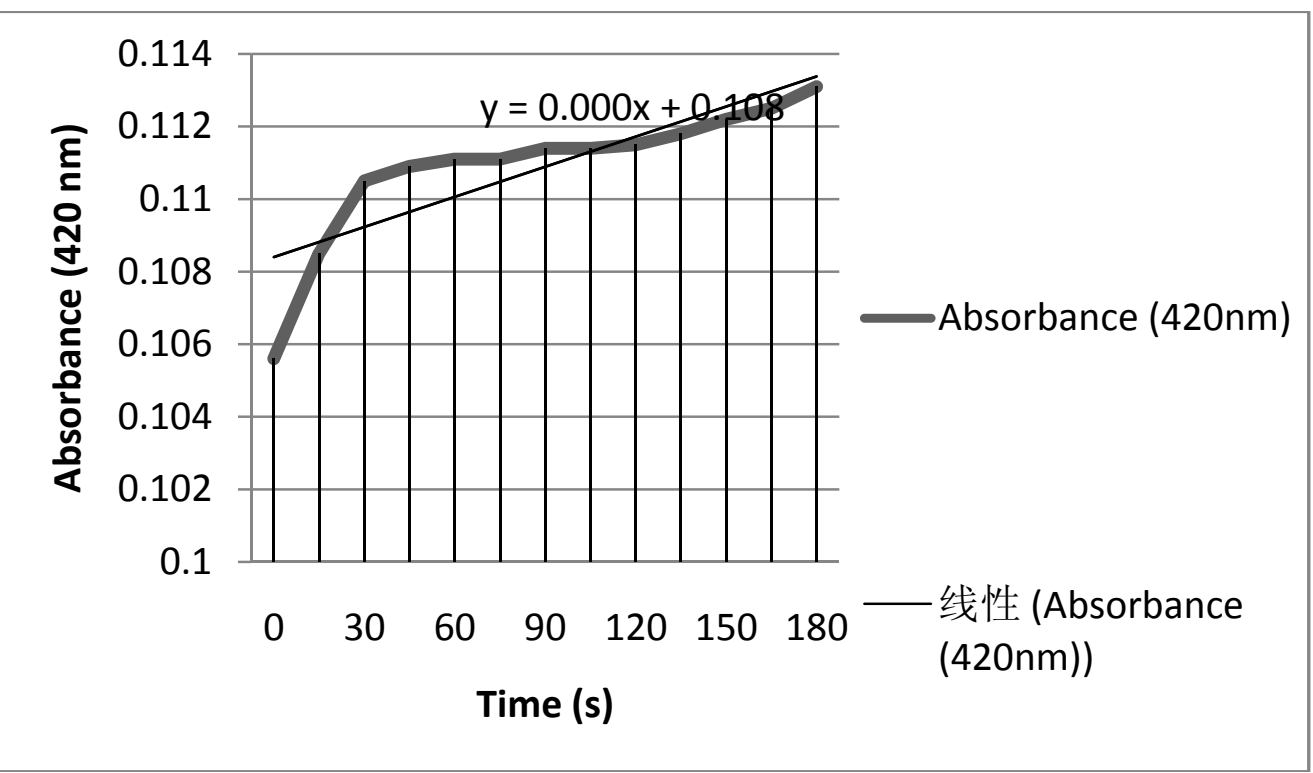

Fig. 3 Absorbance vs. time curve of banana samples treated with ascorbic acid. 


$$
\text { Activity (Unite } / \mathrm{mL} \text { enzyme extract) }=\frac{E}{0.001} \frac{1}{H z}(H r k)(S f)
$$

where, $E$ is the slope of the absorbance vs. time curve, 0.001 is a constant value (using for converting $\mathrm{abs} / \mathrm{min}$ to unit), $H_{\mathrm{e}}$ is the volume of the enzyme extract in the reaction mixture $(\mathrm{mL}), H_{\mathrm{rk}}$ is the total volume of the reaction mixture $(\mathrm{mL})$, and $S_{\mathrm{f}}$ is a dilution factor.

The color and PPO activity results were analyzed statistically by analysis of variance using the General Linear Models (PROC GLM) procedure in SAS (version 9.3, SAS Institute, Inc., Cary, North Carolina, USA). The results analyzed were obtained in triplicate, unless otherwise stated. Differences among the mean values were obtained by Fisher's least significant difference (LSD) test at alpha $=0.05$.

\section{Results}

Fresh-cut bananas are expected to have a bright surface color and be free of decay. The color readings of control and treated banana samples over storage at $4{ }^{\circ} \mathrm{C}$ are shown in Table 1 . The $L$ (lightness) values of all treated banana samples significantly higher than the control at all storage times except first day samples (Table 1). The highest $L$ values were observed for the samples treated with ascorbic acid. The $L^{*}$ values decreased significantly with the storage time in all treated samples including control. The $a$ (redness) values of the bananas significantly increased during storage (Table 1). While the lowest $a$ values were observed on day 0 (for all the treatments), the highest $a$ values were observed on day 14. Similarly, the $b$ (yellowness) values of the bananas significantly increased with the storage time in all samples (Table 1). An increase in redness (a) and yellowness (b) values, and a decrease in lightness $(L)$ values indicated an increased enzymatic browning in all cut bananas during 2 weeks of storage. Pérez-Gago et al. [12] also reported similar results where color changes of apple pieces were featured by a decrease in $L$ (lightness) values, and increase in $a$ (redness) and $b$ (yellowness) values during the storage.

The surface pictures of banana sliced with different chemical treatments are shown in Fig. 2. The samples

Table 1 Color changes in control and treated banana samples over storage at $4{ }^{\circ} \mathrm{C}$.

\begin{tabular}{|c|c|c|c|c|}
\hline Treatments & Storage (days) & $L$ & $a$ & $b$ \\
\hline \multirow{3}{*}{ Control } & 0 & $80.3 \pm 0.8^{\mathrm{a}}$ & $-0.8 \pm 0.2^{\mathrm{d}}$ & $11.9 \pm 0.2^{\mathrm{c}}$ \\
\hline & 7 & $71.3 \pm 0.6^{\mathrm{d}}$ & $1.9 \pm 0.1^{\mathrm{b}}$ & $15.3 \pm 0.1^{\mathrm{b}}$ \\
\hline & 14 & $64.2 \pm 0.8^{\mathrm{e}}$ & $2.6 \pm 0.2^{\mathrm{a}}$ & $18.2 \pm 0.4^{\mathrm{a}}$ \\
\hline \multirow{3}{*}{ Ascorbic acid } & 0 & $80.4 \pm 0.3^{\mathrm{a}}$ & $-0.6 \pm 0.4^{\mathrm{d}}$ & $11.6 \pm 0.4^{\mathrm{a}}$ \\
\hline & 7 & $77.3 \pm 0.4^{\mathrm{b}}$ & $-0.4 \pm 0.4^{\mathrm{a}}$ & $12.1 \pm 0.2^{\mathrm{c}}$ \\
\hline & 14 & $74.2 \pm 0.9^{\mathrm{c}}$ & $0.6 \pm 0.5^{\mathrm{c}}$ & $12.3 \pm 0.3^{\mathrm{c}}$ \\
\hline \multirow{3}{*}{ Sodium carbonate } & 0 & $79.8 \pm 0.6^{\mathrm{a}}$ & $-0.7 \pm 0.3^{\mathrm{d}}$ & $11.3 \pm 0.3^{\mathrm{a}}$ \\
\hline & 7 & $74.2 \pm 0.9^{c}$ & $0.5 \pm 0.8^{\mathrm{c}}$ & $12.5 \pm 0.3^{\mathrm{c}}$ \\
\hline & 14 & $71.7 \pm 0.5^{\mathrm{d}}$ & $1.5 \pm 0.5^{\mathrm{b}}$ & $15.4 \pm 0.2^{b}$ \\
\hline \multirow{3}{*}{ Calcium chloride } & 0 & $79.1 \pm 0.3^{\mathrm{a}}$ & $-0.6 \pm 0.3^{\mathrm{d}}$ & $10.9 \pm 0.3^{\mathrm{a}}$ \\
\hline & 7 & $74.2 \pm 0.5^{\mathrm{c}}$ & $0.5 \pm 0.3^{\mathrm{c}}$ & $12.2 \pm 0.2^{\mathrm{c}}$ \\
\hline & 14 & $70.9 \pm 0.6^{\mathrm{d}}$ & $1.6 \pm 0.2^{\mathrm{b}}$ & $15.6 \pm 0.5^{\mathrm{b}}$ \\
\hline \multirow{3}{*}{ Citric acid } & 0 & $79.3 \pm 0.6^{\mathrm{a}}$ & $-0.6 \pm 0.3^{\mathrm{d}}$ & $10.5 \pm 0.1^{\mathrm{a}}$ \\
\hline & 7 & $74.7 \pm 0.9^{c}$ & $0.7 \pm 0.4^{\mathrm{c}}$ & $15.3 \pm 0.2^{b}$ \\
\hline & 14 & $71.2 \pm 0.6^{\mathrm{d}}$ & $1.8 \pm 0.4^{\mathrm{b}}$ & $15.2 \pm 0.4^{\mathrm{b}}$ \\
\hline \multirow{3}{*}{ Sodium chloride } & 0 & $79.4 \pm 0.7^{\mathrm{a}}$ & $-0.7 \pm 0.3^{\mathrm{d}}$ & $10.8 \pm 0.2^{\mathrm{a}}$ \\
\hline & 7 & $74.3 \pm 0.2^{\mathrm{c}}$ & $0.8 \pm 0.8^{\mathrm{c}}$ & $12.9 \pm 0.3^{\mathrm{c}}$ \\
\hline & 14 & $71.5 \pm 0.5^{\mathrm{d}}$ & $1.5 \pm 0.5^{\mathrm{b}}$ & $15.4 \pm 0.2^{b}$ \\
\hline \multirow{3}{*}{ Hot water $\left(65^{\circ} \mathrm{C}\right)$} & 0 & $78.6 \pm 0.7^{\mathrm{b}}$ & $-0.5 \pm 0.4^{\mathrm{d}}$ & $12.5 \pm 0.1^{\mathrm{c}}$ \\
\hline & 7 & $71.1 \pm 0.3^{\mathrm{d}}$ & $1.5 \pm 0.7^{\mathrm{b}}$ & $15.3 \pm 0.1^{\mathrm{b}}$ \\
\hline & 14 & $70.7 \pm 0.3^{\mathrm{d}}$ & $1.8 \pm 0.5^{\mathrm{b}}$ & $15.3 \pm 0.3^{b}$ \\
\hline \multirow{3}{*}{$\begin{array}{l}\text { Water } \\
\left(25^{\circ} \mathrm{C}\right)\end{array}$} & 0 & $77.3 \pm 0.6^{\mathrm{b}}$ & $-0.4 \pm 0.7^{\mathrm{d}}$ & $12.1 \pm 0.1^{\mathrm{c}}$ \\
\hline & 7 & $71.2 \pm 0.2^{\mathrm{d}}$ & $1.5 \pm 0.2^{\mathrm{b}}$ & $15.7 \pm 0.2^{b}$ \\
\hline & 14 & $65.7 \pm 0.9^{\mathrm{e}}$ & $1.9 \pm 0.4^{\mathrm{b}}$ & $15.9 \pm 0.1^{\mathrm{b}}$ \\
\hline
\end{tabular}

\footnotetext{
${ }^{\mathrm{a}-\mathrm{e}}$ Treatment means within treatments (columns) with the same letter in each sample are not significantly different $(p<0.05)$.
} 
Table 2 PPO activity changes of banana slices during a two-week period at $4{ }^{\circ} \mathrm{C}$.

\begin{tabular}{lll}
\hline Treatments & Storage (days) & PPO activity $(\mathrm{U} / \mathrm{mL})$ at $4^{\circ} \mathrm{C}$ \\
\hline \multirow{2}{*}{ Control } & 0 & $695 \pm 1.3^{\mathrm{c}}$ \\
& 7 & $785 \pm 1.8^{\mathrm{b}}$ \\
Ascorbic acid & 14 & $892 \pm 2.5^{\mathrm{a}}$ \\
& 7 & $174 \pm 2.2^{\mathrm{j}}$ \\
Sodium carbonate & 14 & $183 \pm 3.3^{\mathrm{j}}$ \\
& 0 & $197 \pm 1.8^{\mathrm{j}}$ \\
Calcium chloride & 7 & $252 \pm 4.2^{\mathrm{i}}$ \\
& 14 & $251 \pm 3.8^{\mathrm{i}}$ \\
Citric acid & 0 & $288 \pm 2.8^{\mathrm{h}}$ \\
& 7 & $270 \pm 3.5^{\mathrm{h}}$ \\
Sodium chloride & 14 & $253 \pm 2.7^{\mathrm{i}}$ \\
& 0 & $308 \pm 4.8^{\mathrm{h}}$ \\
Hot water $\left(65^{\circ} \mathrm{C}\right)$ & 7 & $288 \pm 3.2^{\mathrm{h}}$ \\
& 14 & $314 \pm 2.3^{\mathrm{h}}$ \\
Water & 0 & $356 \pm 1.6^{\mathrm{g}}$ \\
$\left(25^{\circ} \mathrm{C}\right)$ & 14 & $292 \pm 2.2^{\mathrm{h}}$ \\
\hline
\end{tabular}

${ }^{\mathrm{a}-\mathrm{j}}$ Treatment means within treatments (columns) with the same letter in each sample are not significantly different $(p<0.05)$.

showed darker colors compared to the ascorbic acid treated bananas (Fig. 2h). This is in agreement with the Hunter $L$ (lightness) readings where ascorbic acid-treated banana slices had significantly higher $L$ values compared to the control. Appearance plays a significant role influencing consumer's perception and subsequent acceptance of a food product. Appearance ranks first affected consumer purchase preferences [13]. It is possible to predict that people will be favor of purchasing bananas treated by ascorbic acid since they have less browning and preferable color.

In this study, different chemical agents including ascorbic acid, sodium chloride, citric acid, calcium chloride, and sodium carbonate were used to reduce the browning of banana slices. The PPO activity changes of banana slices during a two-week period at $4{ }^{\circ} \mathrm{C}$ are listed in Table 2. The PPO activities of bananas treated with ascorbic acid were in the range of 174 to $197 \mathrm{U} / \mathrm{mL}$ during 2 weeks of storage, and that for the Control 695 to $892 \mathrm{U} / \mathrm{mL}$. The PPO activities of all treatments including control significantly increased during storage, especially untreated (control) banana samples. Chemical treatments and immersing banana in water $\left(25^{\circ} \mathrm{C}\right.$ and $\left.65{ }^{\circ} \mathrm{C}\right)$ significantly deceased the PPO activities. Noticeably, ascorbic acid treated banana samples showed lowest PPO activity compared to the other treatments, which is the indication of less browning. This is supported by the color values (Table 1). Ascorbic acid treated samples showed less browning by having a higher $L$ value, and lower $a$ and $b$ values compared to the other treated samples. In overall, the ascorbic acid treated banana samples yielded the best result showing less browning and optimum quality of fresh-cut bananas.

\section{Conclusions}

The quality of banana samples treated with different chemical agents was evaluated for a period of two weeks. A significant difference in color and PPO activity was found between the different treatments. It was observed that the inactivation of PPO enzyme was achieved for the ascorbic acid treated sample most. The ascorbic acid treated banana samples showed 
significantly higher $L$ (lightness) values than that control and other samples. Overall, bananas treated with ascorbic-acid showed a better quality during two weeks of storage compared to the control and other treatments as evidenced by the measurements with instruments, and the appearance of the samples.

\section{References}

[1] Shewfelt, R. L. 1986. "Flavor and Color of Fruits as Affected by Processing." In Commercial Fruit Processing, edited by Woodroof, J. G., and Luh, B. S. Westport, CT: Avi Publishing Co., 481-529.

[2] Huxsoll, C. C., and Bolin, H. R. 1989. "Processing and Distribution Alternatives for Minimally Processed Fruits and Vegetables." Food Technology 43: 124-8.

[3] Whitaker, J. R. 1996. "Enzymes." In Food Chemistry, edited by Fennema, O. R. New York, NY: Marcel Dekker Inc., 431-530.

[4] Marshall, M. R., Kim, J. M., and Wei, C. I. 2000. "Enzymatic Browning in Fruits, Vegetables and Seafoods."

http://www.fao.org/ag/ags/agsi/ENZYMEFINAL/Enzym atic\%20Browning.html.

[5] Caodi, F. 2007. "Characterization of Polyphenol Oxidase and Antioxidants from Pawpaw (Asimina Tribola) Fruit." M.Sc. thesis, University of Kentucky. Paper 477. Retrieved from http://uknowledge.uky.edu/gradschool_theses/477.

[6] Annese, M., Manzano, M., and Nicoli, M. C. 1997. "Quality of Minimally Processed Apple Slices Using Different Modified Atmosphere Conditions." Journal of
Food Quality 20: 359-70.

[7] Gorny, J. R. 1997. "Summary of CA and MA Requirements and Recommendations for Fresh-Cut (Minimally Processed) Fruits and Vegetables." In Proceedings of the Seventh International Controlled Atmosphere Conference, edited by Gorny, J. R., Vol. 5. Postharvest Outreach Program, University of California, Davis, CA, 30-66.

[8] Sapers, G. M., Garzarella, L., and Pilizota, V. 1990. "Application of Browning Inhibitors to Cut Apple and Potato by Vacuum and Pressure Infiltration." Journal of Food Science 55: 1049-53.

[9] Yildiz, G., Rababah, T., and Feng, H. 2016. "Ultrasound-Assisted Cutting of Cheddar, Mozzarella and Swiss Cheeses-Effects on Quality Attributes during Storage." Innovative Food Science \& Emerging Technologies 37: 1-9.

[10] Montgomery, M. W., and Sgarbieri, V. C. 1975. "Isoenzymes of Banana Polyphenol Oxidase." Phytochemistry 14 (s 5-6): 1245-9.

[11] Cemeroglu, B. 2007. "Gida Analizleri." Gida Teknolojisi Dernegi Yayınları. No: 34. Bizim Büro Basımevi. Ankara, 535.

[12] Pérez-Gago, M. B., Serra, M., Alonso, M., Mateos, M., and del Río, M. A. 2005. "Effect of Whey Protein and Hydroxypropyl Methylcellulose-Based Edible Composite Coatings on Color Change of Fresh-Cut Apples." Postharvest Biology and Technology 36: 77-85.

[13] Lund, B. M., and Snowdon, A. L. 2000. "Fresh and Processed Fruits." In The Microbiological Safety and Quality of Food, edited by Lund, B. M., Baird-Parker, A., and Gould, G. W. Aspen, Maryland, MD, USA, 738-58. 